\title{
Rickettsia conorii specific Ig G antibodies: a seroepidemiologic survey in Constanta and Tulcea counties and Bucharest, Romania, 2009
}

\author{
Anticorpi specifici Ig G Rickettsia conorii: studiu seropidemiologic în \\ județele Tulcea şi Constanța şi în Bucureşti, România, în 2009
}

\author{
Roxana I. Serban ${ }^{1 *}$, Iuliana Radu $^{1}$, Irina Codita ${ }^{2,3}$ \\ 1. National Institute of Public Health Bucharest, Romania \\ 2. "Cantacuzino” National Institute of Research-Development for Microbiology and Immunology, \\ Bucharest, Romania \\ 3. "Carol Davila” University of Medicine and Pharmacy, Bucharest, Romania
}

\begin{abstract}
Introduction. Boutonneuse fever $(B F)$ is an emerging infectious disease in Romania evolving in the southern part of the country, as revealed by the incidence rates registered in our previous epidemiological descriptive studies performed during last years. We aimed to evaluate the presence of Rickettsia conorii specific IgG antibodies in a population sample from the affected area. Methods. An ELISA serological survey was performed on 301 serum samples collected from the general population, living in an area most affected by BF, in southern Romania. One of the selection criteria was the absence of signs and symptoms of the disease during the seasonal development of BF. Data were processed in SPSS V.19 (indicators of central tendency, dispersion, frequency and benchmarking). Results. Serological results showed a general positivity rate of $25.2 \%$, with the highest rate in the population group aged over 60 years, this age group accounting for $34.21 \%$ of the whole sample (55.6\% for Bucharest area and 63.16\% for Tulcea district). Conclusions. By confirming the hypothesis based on our previous descriptive epidemiological studies that BF is fitting an endemic pattern in southern Romania, our study results strongly support the need to set up a national surveillance program, aiming at improving BF prevention, management and control in our country. To our knowledge, this is the first study on Rickettsia conorii specific IgG antibodies seroprevalence in Romania.
\end{abstract}

Keywords: Boutonneuse Fever, seroprevalence, southern Romania

\section{Rezumat}

Introducere. Febra butonoasă (FB) este o boală infecțioasă emergentă în România, evoluând în sudul țării, după cum reiese din rata incidenței înregistrată în ultimii ani, conform studiilor noastre anterioare de epi-

${ }^{*}$ Corresponding author: Roxana I. Serban, National Institute of Public Health, Str. Doctor Leonte 1 - 3, Sector 5, CP 050463, Bucharest, Romania

Phone: +40751172422, Fax: 0213180716, E-mail: roxana.serban@insp.gov.ro 
demiologie descriptivă. Ne-am propus să evaluăm prevalența anticorpilor specifici IgG Rickettsia conorii într-un eşantion de populație generală din aria afectată. Metode. S-a efectuat un studiu de seroprevalență prin metoda ELISA pe 301 probe de ser colectate din aria de sud a României; aria cea mai afectată de FB. Unul din criteriile de selecție a fost absența semnelor şi simptomelor caracteristice bolii în perioada de evoluție sezonieră a FB. Analiza statistică. Datele au fost prelucrate statistic cu softul SPSS V.19 (indicatori tendinta centrala, dispersie, frecventa si teste de comparare). Rezultate. Rezultatele serologice au arătat o rata de pozitivitate generală de $25.2 \%$ cu cea mai mare rată de pozitivitate la grupul de populație de peste 60 de ani $34,21 \%$ din totalul probelor de ser (63,6\% pentru județul Tulcea şi $55.56 \%$ pentru Bucureşti). Concluzii. Confirmând ipoteza că FB îmbracă un caracter endemic în sudul României, bazată pe studiile noastre anterioare, studiul de față a adus argumente în sprijinul necesității de a introduce un program național de supraveghere în scopul cunoaşterii reale a incidenței, managementului şi controlului $F B$ în țara noastră. După cunoştintele noastre, acesta este primul studiu de seroprevalență a anticorpilor specifici IgG Rickettsia conorii în România.

Cuvinte cheie: Febră butonoasă, seroprevalență, sudul Romaniei

Received: $24^{\text {th }}$ September 2013; Accepted: $16^{\text {th }}$ November 2013; Published: $25^{\text {th }}$ November 2013.

\section{Introduction}

Since mankind has existed, fleas and lice have been its permanent companions. The price of this companionship is represented by the resulting communicable diseases. Recent studies have shown that the presence of Rickettsia prowazekii nucleic acids was confirmed in soldiers of Napoleon's French army during his Russian campaign (1).

Boutonneuse fever (BF) is a tick-borne disease caused by Rickettsia conorii. It was first described a century ago as a disease with high fever and spots (2).

Rickettsia conorii belongs to the spotted fever group of the genus Rickettsia (family Rickettsiaceae, order Rickettsiales) and is an obligate intracellular coccobacillus that grows within the cytoplasm of its eukaryotic host cells (3).

Boutonneuse fever is often severe and even a fatal zoonozis, transmitted in Europe mainly by Rhipicephalus sanguineus, known as "the brown dogtick".

In Romania, boutonneuse fever was detected for the first time in 1910 by Serafidi. In 1931 V. Vasiliu, G. Barzanescu and D. Combiescu described the characteristics of the illness (4-6).

In a previous descriptive epidemiological study performed in Romania, 2000 - 2008, all cases of BF recorded nationwide came from
Southern Romania. The highest rate of incidence, $1.6 \%$ o00, occurred in 2002 and represented $22.9 \%$ of all cases reported in that period. The high rate of incidence reported in counties Constanta, Tulcea and Bucharest area suggested that BF could be a public health problem for these areas (7).

The temporal distribution respected the maximum activity interval of the vector $R$. sanguineus. The historical seasonality for the boutonneuse fever is June-September; in our previous study we found a trend of extending the reporting interval, as the cases were detected beginning with May. The evolution of boutonneuse fever cases matched the sporadic case pattern (7).

By our present study we aimed to evaluate the prevalence of Rickettsia conorii specific IgG antibodies in a general population sample from the affected area, in order to appreciate the opportunity to set up a national surveillance program of $\mathrm{BF}$ in Romania.

\section{Material and methods}

We performed a serological survey in 2009, on 301 serum samples collected from a randomized sample of the general population selected from areas most affected by $\mathrm{BF}$ in southern Romania: Constanta and Tulcea counties and Bucharest. 
Table 1. Distribution of the serological results by county

\begin{tabular}{|c|c|c|c|c|c|c|c|c|}
\hline \multirow{3}{*}{$\begin{array}{l}\text { ELISA } \\
\text { Results }\end{array}$} & \multicolumn{8}{|c|}{ County } \\
\hline & \multicolumn{2}{|c|}{ Total } & \multicolumn{2}{|c|}{ Bucharest } & \multicolumn{2}{|c|}{ Constanta } & \multicolumn{2}{|c|}{ Tulcea } \\
\hline & Count & $\%$ & Count & $\%$ & Count & $\%$ & Count & $\%$ \\
\hline Total & 301 & $100 \%$ & 99 & $32.9 \%$ & 119 & $39.5 \%$ & 83 & $27.6 \%$ \\
\hline Equivocal & 14 & $4.7 \%$ & 12 & $4.0 \%$ & 2 & $0.7 \%$ & 0 & $0.0 \%$ \\
\hline Negative & 211 & $70.1 \%$ & 69 & $22.9 \%$ & 78 & $25.9 \%$ & 64 & $21.3 \%$ \\
\hline Positive & 76 & $25.2 \%$ & 18 & $6.0 \%$ & 39 & $13.0 \%$ & 19 & $6.3 \%$ \\
\hline
\end{tabular}

According to the incidence data from the year $2008\left(11.11 \%_{000}\right.$ rate of incidence for Constanta county $15.26 \% 000$ rate of incidence for Tulcea county and $0.41 \%_{000}$ for Bucharest area) (7), the representative population sample should have been 360 persons. After applying our selection criteria (volunteers without signs or symptoms of the disease investigated for other diseases in the period of time that corresponded to the maximum activity of the $R$. sanguineus tick according to the lab capacity), our sample included 301 persons.

All persons included in this serologic study, or their parents for children younger than 18 years, signed an informed consent form expressing their agreement to participate in this study. Sex and age were recorded for all persons included.

Sera were stored at $-20^{\circ} \mathrm{C}$ until tested at the National Institute of Public Health, Bucharest, for IgG $R$. conorii specific antibodies, by an ELISA method, using an ImmunoLISA Rickettsia conorii IgG/IgM kit (Orgenics Ltd). Performance parameters of the ELISA kit used in this study were: $100 \%$ specificity and $85 \%$ sensitivity, as determined by the manufacturer.

Antibody index was defined as the fraction between sample O.D. (optical density) and cut off serum mean O.D. multiplied by 10 . The antibody index for a positive reaction was $>11$, as indicated by the manufacturer. Equivocal results were in the range of 9-11, while antibody indexes less than 9 were considered negative reactions.

Samples with indexes below 9 were considered as not having IgG specific antibod- ies against $R$. conorii. Samples with indexes above 11 were considered as having IgG specific antibodies against $R$. conorii. Samples with equivocal results were retested.

Data were processed with SPSS V 19. The distribution by age of our sample was tested using statistics of central tendency, histogram of ages and measurements of the central tendency. Differences in the distribution of the positive samples among the age groups according to the county of provenience were tested using Kruskal-Wallis test, significant difference was considered when $\mathrm{p}<0.05$.

\section{Results}

In this study were enrolled 301 persons.

The highest positive rate was found in Constanta county $(51.32 \%$ from the total positive samples). The distribution of the serological results is presented by county in Table 1 .

From the tested sera, 161 (53.49\%) samples were collected from females. The distribution of positivity by gender and county is presented in Table 2.

Statistical analysis of the age of the selected population sample displayed an asymmetrical distribution curve showing right skewness with the larger number of subjects having ages over 21 years (79 cases)

The amplitude of age group distribution was 90 years (inferior limit 1 year and superior limit 90 years), suggesting that the disease 
Table 2. Distribution of positive samples by gender and county

\begin{tabular}{lccc}
\hline County & Female & Male & Total \\
\hline Bucharest & $11(29.7 \%)$ & $7(17.9 \%)$ & $18(23.7 \%)$ \\
Constanta & $17(45,9 \%)$ & $22(56.4 \%)$ & $39(51.3 \%)$ \\
Tulcea & $9(24.3 \%)$ & $10(25.6 \%)$ & $19(25 \%)$ \\
\hline Total & $37(100 \%)$ & $39(100 \%)$ & $76(100 \%)$ \\
\hline
\end{tabular}

Table 3. Seropositivity rates by age group and geographical area

\begin{tabular}{lccccccc}
\hline County & $\mathbf{1 - 2 0} \mathbf{y}$ & $\mathbf{2 1 - 3 0} \mathbf{y}$ & $\mathbf{3 1 - 4 0 ~} \mathbf{~}$ & $\mathbf{4 1 - 5 0} \mathbf{y}$ & $\mathbf{5 1 - 6 0} \mathbf{y}$ & Over 60 y & Total \\
\hline Bucharest & $2(11.11)$ & $5(27.78)$ & 0 & 0 & $1(5.56)$ & $10(55.56)$ & 18 \\
Constanta & $5(12.82)$ & $8(20.51)$ & $5(12.82)$ & $8(20.51)$ & $9(23.08)$ & $4(10.26)$ & 39 \\
Tulcea & 0 & $2(10.53)$ & $1(5.26)$ & 0 & $4(21.05)$ & $12(63.16)$ & 19 \\
\hline Total & $7(9.21)$ & $15(19.74)$ & $6(7.89)$ & $8(10.53)$ & $14(18.42)$ & $26(34.21)$ & $76(25.20)$ \\
\hline
\end{tabular}

Results expressed as number of positive samples (percentage).

reaches all groups of age. The group was strongly inhomogeneous for age distribution (standard deviation is 19.5 years) with a median age of 39 years and a modal age of 29 years.

Of the tested sera, $25.20 \%$ were positive for the presence of Ig G $R$. conorii specific antibodies. Most $R$. conorii specific IgG positive sera were found in the $60+$ age group, followed by the 21 - 30 age groups (Table 3). The highest positive rate was registered in Constanta county (13.\%).

From the 76 positive sera, 53.16\% were from females, while $46.84 \%$ were from males: the positive rate by gender was $23.12 \%$ for females and $27.65 \%$ s for males.

The highest positive rate was found in the age group of over 60 years, both in the general sample $(34.21 \%)$ and for each of the studied geographical areas: $66.67 \%, 47.61 \%$ and $35.29 \%$ for Constanta county, Bucharest and Tulcea county, respectively. For Constanta county we found 5 cases out of 13 positive for Rickettsia conorii specific IgG antibodies, belonging to the $0-21$ age group. This finding has to be further investigated, as it represents clinically and epidemiologically valuable information which needs to be integrated (Table 3).
Because the age distribution of our sample was inhomogeneous we tested the hypothesis according to which there were statistically significant differences between the median ages of the positive cases between counties, using the Kruskal-Wallis test. This hypothesis was rejected $(\mathrm{p}=0.0001)$.

\section{Discussions}

Transmission of rickettsiae in humans may occur directly, as a result of infected tick bite or crushing the tick on the skin, or indirectly, by mucosal entry, through contaminated hands (8).

$\mathrm{BF}$ is known also as Mediterranean spotted fever (MSF) or Israeli spotted fever.

The abundance of the tick itself is an important determinant of the disease prevalence and is influenced by many factors, including climatic and ecologic conditions (9, 10). Climatic variations are suspected to play an important role in tick activity and, consequently, on rickettsial prevalence $(11,12)$.

The risk of ticks transmitting Rickettsiae and the prevalence of a specific tickborne disease is dependent on several parameters. The 
prevalence of Rickettsia - infected ticks, which can vary greatly, is important. For example, up to $12 \%$ of Rhipicephalus sanguineus ticks are infected with $R$. conorii in southern France (13), whereas only $0.5 \%$ of $D$. variabilis ticks in North Carolina are infected by $R$. rickettsii (14). The affinity of a specific tick for human beings also varies. For example, in Mediterranean countries, although nearly everybody is in contact with the dog tick Rhipicephalus sanguineus, the prevalence of BF is only 50 per 100,000 inhabitants. The reason is the low affinity of this tick for hosts other than the dog.

A study performed in Israel demonstrated that Rhipicephalus sanguineus ticks fed on dogs and hedgehogs were infected with $R$. conorii but the role of vertebrate reservoirs in maintaining zoonotic foci has yet to be clarified (15).

Recently BF appears to be a more severe disease than it was in the past. Thus, reported mortality rates were $3.2 \%$ in Oran, Algeria, in 2004 (16) and even 32.3\% in hospitalized patients in Beja, Portugal, in 1997 (17). This increase in severity has not been explained yet. But BF is now more quickly recognized and treated with more effective antimicrobial drugs than in the past. Based on these, we are expecting better outcome of BF. This was the case for RMSF (Rocky Mountain spotted fever), which caused mortality rates in the United States of 2.4\% during 1993-1996 (18) and 1.4\% during 1997-2002 (19), in contrast to a mortality rate of $65 \%-90 \%$ at the beginning of the century.

A hypothesis explaining the higher mortality rates could be that severe forms of spotted fever cases were not easily recognized in the near past. In fact, BF was considered to be a benign disease before the 1980s (20). BF was not considered as a possible diagnosis for patients hospitalized in intensive care units with a febrile rash. Compared to RMSF, BF was considered a benign disease for 70 years, therefore its real severity was long time ignored. Although the mortality rate was evaluated to be 1$3 \%$ in the early reports in the literature, the first description of a highly severe form of BF was published in the early 1980s (21). Nowadays, we know that BF is at least as severe as RMSF.

Another hypothesis for the higher mortality could be that more virulent strains of $R$. conorii appeared in last years (22).

Data from the Romanian National Centre for Statistics compared national and regional incidence of BF between 2000 and 2009. According to these, BF may represent a public health problem for some regions. Tulcea, Constanta and Bucharest areas presented high prevalence of BF cases over the years: in 2001 the highest prevalence was registered in Constanta $\left(44.2 \%_{000}\right)$, in 2002 the prevalence of BF was $39 \%_{000}$ in Tulcea; for Bucharest the prevalence over the years was higher than in the rest of the southern Romanian districts (for example, in 2003 it was 2 times higher than the national baseline level) (23).

Reported cases from our previous epidemiological study had serological diagnosis performed in only 38\% (7). Data obtained in the present serological study showing a positive rate of $25.2 \%$ of the sample (13\% Constanta,6\% Bucharest and $6.3 \%$ Tulcea) strengthen the idea that $\mathrm{BF}$ is a public health problem in these areas.

Possible bias in respect of positive rates by geographical area may be due to the fact that our sample is not a representative one, this highlighting again the need for BF surveillance.

\section{Conclusions}

Although our general population sample was not representative for the counties, by the present seroprevalence study we reached our goal to better understand BF seroepidemiology in Romania. It strengthens the hypothesis based on our previous descriptive epidemiological studies that this tick borne zoonosis is fitting an endemic pattern in southern Romania.

Evidence provided strong support for the necessity to further investigate the real amplitude of the disease and promotes the need to 
set up a national surveillance program, aiming the prevention, management and therapy of $\mathrm{BF}$ in our country.

To our knowledge, this is the first seroepidemiological study of BF in Romania.

\section{References}

1. Dobler G, Wölfel R. Typhus and Other Rickettsioses Emerging Infections in Germany. Dtsch Arztebl Int, 2009, 106(20):348-54.

2. Parola P, Paddock C, Raoult D. Tick-borne rickettsioses around the world: emerging diseases challenging old concepts. Clin Microbiol Rev. 2005, 18:719-56.

3. Raoult D. Emerging rickettsioses reach the United States. Clin. Inf. Dis., 2010, 51(1):121-122.

4. Combiescu D: Sur une epidemie de fievre exanthematique, fievre boutonneuse ou fievre escharo-nodulaire. Arch Rom Path Exp, 1992, 2:23-25.

5. Combiescu D, Dumitrescu N, RussM: Considerații epidemiologice asupra unor cazuri de febră butonoasă ivite în ultimii 41 de ani; Stud.Cercet.Inframicrobiologie, Bucureşti. 1953, 1-2 :99-102.

6. Constantinescu N, Marinescu Gh - Febra butonoasă (Boutonneuse fever - Rom.) in Elemente de inframicrobiologie specială (Special inframicrobiology elements Rom.), Ed. Nicolau, St S, Ed. Medicală, Bucureşti, 1962:738-740.

7. Serban R: Boutonneuse Fever in Romania between 2000-2008, Bulletin of the Transilvania University of Brasov. 2012 ,5 (54):63-70.

8. Azoicai, Doina: Febra butonoasa, Epidemiologie speciala - Tratat de epidemiologie a bolilor transmisibile.Iasi: Editura Polirom, 2002. 428.

9. Hattwick M A, O'Brien R J, Hanson B F. Rocky Mountain spotted fever: epidemiology of an increasing problem. Ann Med Interne, 1976, 84:732-739

10. Mansueto S, Tringali G, Walker DH. Widespread, simultaneous increase in the incidence of spotted fever group rickettsiosis. J Infect Dis. 1986, 154:539-540.

11. Parola P, Paddock C, Raoult D. Tick-borne rick- ettsioses around the world: emerging diseases challenging old concepts. Clin Microbiol Rev. 2005, 18:719-56.

12. Espejo Arenas E, Font Creus B, Bella Cueto F, Segura Porta F - Climatic factors in resurgence of Mediterranean spotted fever [letter]. Lancet, 1986, 1:1333 - 1333. 13. Peter O, Raoult D, Gilot B. Isolation by a sensitive centrifugation cell culture system of 52 strains of spotted fever group rickettsiae from ticks collected in France. J Clin Microbiol. 1990, 28:1597-1599.

14. Walker DH, Fishbein D B. Epidemiology of rickettsial diseases. Eur J Epidemiol. 1991, 7:237-245.

15. Harrus S, Lior Y, Ephros M, Grisaru-Soen G, Keysary A, Strenger C et al. Rickettsia conorii in humans and dogs: A seroepidemiologic survey of two rural villages in Israel. Am J Trop Med Hyg. 2007, 77(1):133-135.

16. Mouffok N, Benabdellah A, Richet H, Rolain JM, Razik F, Belamadani D et al. Reemergence of rickettsiosis in Oran, Algeria. Ann NY Acad Sci. 2006, 1078:180-184.

17. De Sousa R, Nobrega SD, Bacellar F, Torgal J. Mediterranean spotted fever in Portugal: risk factors for fatal outcome in 105 hospitalized patients. Ann. NY Acad. Sci. 2003 Jun, 990:285- 94.

18. Treadwell TA, Holman RC, Clarke MJ, Krebs JW, Paddock CD, Childs JE - Rocky Mountain spotted fever in the United States, 1993-1996. Am J Trop Med Hyg. 2000, 63:21-26.

19. Chapman AS, Murphy SM, Demma LJ, Holman RC, Curns AT, McQuiston JH et al. Rocky Mountain spotted fever in the United States, 1997-2002. Vector Borne Zoonotic Dis. 2006, 6:170-178.

20. Olmer D, Olmer J. Répartition géographique actuelle de la fièvre boutonneuse. Mars Med. 1957, 8:525-536.

21. Raoult D, Kohler J L, Gallais H, de Micco P, Rousseau S, Casanova P. Fatal rickettsiosis (letter). Nouv Presse Med. 1982, 11(8):607.

22. Fournier PE, El Karkouri K, Leroy Q, Robert C, Giumelli B, Renesto P et al. Analysis of the Rickettsia africae genome reveals that virulence acquisition in Rickettsia species may be explained by genome reduction. BMC. 2009, 10:166-181.

23. Raport pentru anul 2009. Analiza evoluției bolilor transmisibile aflate în supraveghere. Institutul Național de Sănătate Publică. 2010:67-70. 